\title{
The Unprescence of China's COVID-19 Trauma and Its Impact on Social Identity
}

\author{
Yan Huang ${ }^{1}$ \\ ${ }^{1}$ Foreign Language School, Sichuan University of Science and Engineering, Zigong, Sichuan, China \\ Correspondence: Yan Huang, Foreign Language School, Sichuan University of Science and Engineering, Zigong, \\ Sichuan, China. E-mail: atreerlove@126.com
}

Received: September 15, 2021

Accepted: October 22, 2021

Online Published: November 4, 2021

doi:10.5539/ells.v11n4p48

URL: https://doi.org/10.5539/ells.v11n4p48

\begin{abstract}
In the psychology and literary fields, the theoretical study of trauma has received increasing attention. It is widely applied by experts and scholars across various aspects, such as war, gender and so on. To give it more practical significance, the main object of this study is to investigate the modern use of trauma by connecting it to the topic of a nation. China, the country first plagued by COVID-19-a representative modern trauma - has suffered not only physically but also mentally. This paper will analyze how trauma affects a nation by using classical theories on trauma, such as those from Sigmund Freud and Cathy Caruth. In terms of national collective trauma, new theories from Roger Luckhurst and Jeffrey C. Alexander would also be adopted. To achieve the sophisticated link between trauma and nation, the unprescence of trauma and its social identity threat to China are further discussed as main parts of this essay. This research will encourage a more rational treatment of collective trauma sufferers and calls for the realistic and practical use of the literary trauma theory.
\end{abstract}

Keywords: trauma, COVID-19, China, unprescence, collective trauma, social identity

\section{Introduction}

The literary study of trauma was first introduced by Freud and then became more focused with the recognition of post-traumatic stress disorder (PTSD), which describes a psychological disease stemming from a severe traumatic experience. The term was initially used when referring to individuals suffering from catastrophic events, but the scope was eventually widened to include those who were indirectly involved. Luckhurst named those who were indirectly involved "the second victims," which "includes witnesses, bystanders, rescue workers, relatives" (Roger, 2008). In this essay, the suffering of directly and indirectly involved will be articulated and, therefore, national collective trauma is also worthy of discussion. As a nation that has experienced the striking pandemic of COVID-19, China can be explored as an important case in terms of trauma study.

In the previous study of trauma, in Beyond the Pleasure Principle (1920), the leading theorist Sigmund Freud analyzed trauma more from psychological field, such as people's reaction to trauma. Cathy Caruth, a classical scholar expanded the research then into literary criticism by focusing on the connection of trauma and language in her significant works of Trauma: Explorations in Memory (1995) and Unclaimed Experience: Trauma, Narrative, and History (1996). Then, other than individual trauma sufferers, more attention is paid to group traumatic experiences. In Cultural Trauma and Collective Identity (2004) by Jeffrey C. Alexander and The Trauma Question (2008) by Roger Luckhurst both stated that a traumatic event would permanently influence a nation's identity.

In this essay, based on the theories above, it mainly discusses how trauma could work on a specific nation and how a traumatic event influences a nation's identity from different aspects by combining the traditional theories on trauma and modern ones on national collective trauma.

\section{The Theoretical Development of Trauma}

Since the Vietnam war, the study of trauma has become more focused. Until 1980, PTSD was officially used by the American Psychiatric Association as a pathological term to describe victims who have suffered a traumatic experience. "Individuals who experience wars, disasters, accidents or other extreme 'stressor' events seem to produce certain identifiable somatic and psycho-somatic disturbances" (Roger, 2008). Alongside theoretical development, and based upon Freudian study, many scholars have delved into further analysis of trauma from 
different perspectives.

\subsection{Early Freudian Research on Trauma}

According to early Freudian theory, people pursue gratification according to the pleasure principle. More accurately, we are forced to forget painful events through our protective instinct, namely, the pleasure principle or life instinct. However, in 1920, after pondering upon the violence of the war, Freud discovered that the cruelty of the war does not conform with the former idea. After analyzing the symptoms of many war victims, Freud noticed they were haunted by a repetitive compulsion and occurrence of traumatic memories. In Beyond the Pleasure Principle, Freud suggested the famous death drive or death instinct. It was later interpreted that people are actually driven by the death instinct. It enables people to assault others and trigger wars. When an external assault cannot be achieved due to obstacles, it transfers to an internal destruction, such as self-reproach, or suicide. The death drive is a repetitive, traumatic and negative experience. Based on this view, Freud also suggested that traumatic memory is repetitive and belated. Many researchers followed this idea and built their studies on Freud's fundamental features of trauma.

\subsection{Unspeakable Trauma by Cathy Caruth}

Since Freud introduced the notion of trauma, it has gained popularity as an interdisciplinary subject, involving psychoanalysis, psychiatry, cultural, sociology, and politics. Cathy Caruth took the lead in Literary criticism by publishing Trauma: Explorations in Memory (Cathy, 1995) and Unclaimed Experience: Trauma, Narrative, and History (Cathy, 1996). Different from Freud, she paid much attention to the language side but it is Freud's theories on trauma that gives her the chance to lead the topic further into literary criticism. As a student of Paul de Man, Caruth "pioneered a psychoanalytic post-structural approach that suggests trauma is an unsolvable problem of the inherent contradictions of experience and language" (Michelle, 2014). Caruth held the same view as many scholars that trauma is unspeakable. Owing to its inherent belatedness and the punctual trauma model, the reality of trauma is also disruptive. "Trauma is experienced too soon, too unexpectedly, to be fully known and is therefore not available to consciousness until it imposes itself again, repeatedly, in the nightmares and repetitive actions of the survivor" (Cathy, 1996). While "the history of a trauma, in its inherent belatedness, can only take place through the listening of another" (Cathy, 1995). Without direct access to traumatic events as they occur, survivors' uncertainty triggers a truth crisis and an historical reality debate.

\subsection{Theories on National Collective Trauma}

The focus on trauma originally focused on individual traumatic experiences. With the passing of time, people noticed "concentration camp inmates, Vietnam and Gulf War veterans, victims of atrocities..." (Roger, 2008). To a large extent, trauma sufferers also include "secondary victims," which "include witnesses, bystanders, rescue workers, relatives" (Roger, 2008). This study of contemporary trauma culture is, therefore, also concerned with collective national or group memories. Apart from the historical events mentioned above, contemporary trauma research is also linked to gender, colonization, natural catastrophes and so on. Roger Luckhurst and Jeffrey C. Alexander proposed constructive ideas on national collective trauma and cultural trauma. From the introduction of Cultural Trauma and Collective Identity, Alexander provided scrupulous analysis, which suggested that when an individual or group experiences a catastrophic event, its ineffaceable track makes it a permanent memory. As a result, an individual or group's future would be radically and irreversibly changed (Jeffery, Ron, Bernhard, Neil, \& Piotr, 2004). In Luckhurst's The Trauma Question, he states that "traumatic identity is now also commonly argued to be at the root of many national collective memories" (Roger, 2008).

\section{The Unpresence of COVID-19 Traumatic Memory}

In 2019, a devastating pandemic called COVID-19 started to spread across the world, including China. It is highly contagious and fatal. Due to improvements in the development of the media system and government transparency during recent decades, people have been informed about the death toll and rates of infection of the virus. The disease is torturous and frightening. However, does it really have much of a negative impact on people's mentality? Surprisingly, the answer may be "no". In the following sections of this article, I aim to explore why COVID-19 is now unpresent, particularly for Chinese people, especially as the country first to suffer a severe attack from the virus. Evidence from the perspectives of psychology, philosophy and literature will be delineated to explain the trauma's unpresence.

\subsection{Absence from Consciousness}

Months after the occurrence of COVID-19, people are dazed and have no real understanding of the horror and recognition of horror and the sublime. People suddenly experienced and witnessed a devastating pandemic. Without full preparation, they have found it difficult to respond. During a period of time, people do not 
understand what they have experienced and COVID-19 remains unpresent to them. In terms of the absence of consciousness, Laub Dori attributed this to the "collapse of witnessing." "The inability fully to witness the event as it occurs, or the ability to witness the event fully only at the cost of witnessing oneself" (Dori \& Shoshana, 1991). Cathy Caruth also explains this through her punctual model of trauma: "That is experienced too soon, too unexpectedly, to be fully known..." (Cathy, 1996). This symptom is similar to the notion of sublime put forward by Kant. In his analysis of trauma, Jean-François Lyotard compares the feeling of trauma with that of the sublime. Namely, we cannot express what it is when our sensory faculties are awed by something (Jean, 1984). This analogy also articulates the absence of consciousness when trauma occurs.

From the analysis of Allan Young's work, Ronald Mather and Jill Marsden discuss an assumption in Trauma and Temporality. They indicate that sufferers feel the pain and torture of a trauma but without knowing or recognizing the reality of the traumatic event. It is assumed that there is an inversion of the traumatic event sequence and symptoms of stress. Later in the text, this is explained by an argument: "Life must be lived forward but can be understood only retroactively" (Mather \& Jill, 2004). This might explain why people feel something different about the occurrence of COVID-19 but are not aware what it is. Life always moves forward. Only when we look back or when we are stimulated by a homogeneous event can we reflect upon it.

This does not mean that victims are unharmed or can rid themselves of the traumatic experience. Instead, it is belated in their memories. Between the trauma and the return of the traumatic memory, victims suffer nightmares and repetitive flashbacks of an incident.

\subsection{The Repression of the Trauma of COVID-19}

In the last section, we analyzed the absence of consciousness after the occurrence of a traumatic event. People are unaware of the occurrence of an event because it happens too soon. Nonetheless, is it possible also to presume that this is because people's fear of the experience has not yet been awakened. In other words, the severity of COVID-19 was underestimated, because the repression made people unconscious of its occurrence. Clues from Freudian trauma theory shed light on this notion.

The idea of trauma repression is elucidated by Cathy Caruth when she analyzes Freud's interpretation of the Moses and Monotheism repression and return. Moses is a hero who guides the Hebrews to escape from Egypt to Canaan. This departure is said to be a new beginning, because Moses wanted to preserve the Monotheistic religion. However, later, during a rebellion, the Hebrews killed Moses, their leader, and repressed the murder. After two generations, they assimilated Moses' god to a volcano god named Yahweh and changed the liberation acts of Moses into that of the new leader, Yahweh. Later, Yahweh had exactly the same name as Moses. With a second god and a similar god, Hebrews, later Jews, finally realized the trauma of the murdered Moses and finally, their memories of Moses and his deeds returned.

From this analysis above, it seems that repression ends with a final return of the traumatic experience. "It is fully evident only in connection with another place, and in another time" (Cathy, 1996). This is proven by the occurrence of a previous horrifying pandemic in China, namely, SARS. The infectious disease broke out in 2003 and attacked China and its entire nation. Then, in 2019, COVID-19 spread all over the world. The two epidemics are both highly contagious and fatal. However, in relation to people's mentality, why did SARS not exert as much impact on society as COVID-19? Some would argue that this is attributed to the fact that media systems and government transparency have improved during the last decade. However, as well as these external considerations, there are internal factors that can account for people's silence regarding the traumatic event. That is, COVID-19, a homogeneous epidemic, serves as a good inducement for SARS to have its repressed memory returned. Likewise, if attempting to reflect on the history of the truth of COVID-19, people have to go through the same process as they did with SARS. A period of repression is unavoidable before people can truly make an unpresentable history presentable. On the outbreak of the next pandemic, the intact history of COVID-19 would ultimately return to people.

\subsection{The Features of the Language of Trauma}

\subsubsection{The Distortion of the Language of Trauma}

As mentioned in the first section, owing to its inherent belatedness and the punctual trauma model, traumatic memory is unspeakable. Anne Whitehead even made this clear in Trauma Fiction. But, before we embark upon further discussion of this question, some may think that, because it is difficult to relate trauma to language, there is no point in discussing trauma fiction. However, it is through the analysis of the trauma fiction that we might discover the fundamental language features of trauma.

According to Whitehead, trauma fiction is related highly to three main backgrounds or contexts and, here, we 
focus mainly on the language study of postmodernism. Because it aims to challenge conventional narrative techniques and forms, a strange postmodern language style emerges, comprising repetition, distortion, obscurity and so on. Thus, having interacted with postmodernism, "narratives are characterized by repetition and indirection" (Anne, 2004). "Trauma fiction seeks to ... convey the damaging and distorting impact of the traumatic event" (Anne, 2004) and "writers of trauma narratives push the realist project to its limit... in order to suggest that traumatic knowledge cannot be fully communicated or retrieved without distortion" (Anne, 2004). Most of the time, paper material written about a traumatic experience is often recorded immediately after an event. People are often unable to truly understand a traumatic event immediately after its occurrence. In addition, the distorted language used makes it impossible for people to recognize the extent of the trauma.

\subsubsection{The Invented Trauma Narratives}

Furthermore, as indicated by Ronald Mather and Jill Marsden in Trauma and Temporality, "PTSD is a condition that one is obliged to "invent"' (Mather \& Jill, 2004), because in consciousness, a traumatic event is not present due to the dissociative or sensory memory, that is, it is unavailable to consciousness. Bessel argues that "the very nature of traumatic memory is dissociative, and to be stored initially as sensory fragments that have no linguistic components" (Van der Kolk, 1996). He also mentions that, when trauma occurs, the subjects remember the trauma as somatosensory flashback experiences. Later, when subjects are telling their traumatic stories to others, they rely only on their fragmented memories and intuitive feelings. The traumatic experience at the start is not in narrative form and is without a communicative function. When subjects recollect more memory fragments, they seem to construct or weave a narrative. Bessel concludes that "all narratives that weave sensory imprints into socially communicable stories are subject to condensation, embellishment and contamination" (Van der Kolk, 1996). It is not difficult to conclude that the language of trauma itself is weaved and invented from the idea of former storytellers. We can boldly assume that the traumatic event of COVID-19 might be interpreted by unrealistic paperwork and media reports.

\subsection{The Historical and Political Influence on the Presence and Unpresence of Trauma}

It was previously discussed that trauma narratives are invented from the perspective of language. Here, for the invention of trauma, still in Trauma and Temporality, Ronald Mather and Jill Marsden emphasize that it is also related to politics. They clarify this claim by mentioning an idea from Allan Young. He admits that, from a psychological perspective, trauma is disturbing and painful for the sufferers. However, what is shocking here is that trauma is probably also invented from the perspective of politics. He exemplifies this by explaining that when PTSD was included in Diagnostic and Statistical Manual of Mental Disorders III (DSM-III), "it was the result of political lobbying for the recognition of the post-war suffering of Vietnam veterans" (Allan, 1995; Young, 1995). The recognition of trauma or PTSD, however, just served as a preface. Subsequently, other people used this to seek recognition of the suffering people have experienced from other types of trauma in the past. Thus, from his point of view, it is implicated that politics can exert influence on the definition and recognition of trauma. According to Young, psychological health and illness would not be totally grasped in isolation from people's social and political conditions of emergence. "In this respect, his argument that PTSD is historically contingent is a transcendental one: the aim is to establish what gives the 'given' —or, to express it more simply, to establish which factors serve to constitute a particular phenomenon as real" (Mather \& Jill, 2004).

This discussion reminds us that, for a better understanding of the reality or true status of a traumatic event or memory, we should take politics into consideration. Then, we could explain why COVID-19 is now not as available to everyone or not so imprinted into the memories of Chinese people. Without a full understanding of such a severe pandemic, it is understandable and predictable that any political regime would assume they have the ability and confidence to cope with it. However, when the situation becomes clearer, to maintain social order, many governments would try to underestimate or repress the reality. The Chinese nation is not an exception. During the fight against this virus, a host of positive and encouraging news has been informed by the government. For instance, professional specialists, doctors, and nurses were dispatched to help people in the worst-hit areas. Chinese civilians from all walks of life have taken measures to show their determination in coping with the virus, such as community workers, delivery people, volunteers. The tactic adopted by the government lessened people's fear, thus masking the severity of the virus. From these perspectives, it could also explain why COVID-19 is not particularly alarming.

\subsection{The Unpresence of Trauma due to the Ethical Bond}

In previous sections, a reason for traumatic memories being unpresentable is expressed. In the following text, I will reinterpret the unpresent traumatic memory of COVID-19 from an ethical perspective.

In "Tuché and Automaton," Jacques Lacan relates the unpresence of the traumatic events to the identity of 
oneself and to one's relationship with other people (Shoshana, 1985). He exemplifies this by rethinking Freud's story of the burning child. In the story, a child dies from a fever and his body catches fire. At the time, the father is sleeping due to exhaustion and he employs a man to keep an eye on the boy. But the man neglects his duty by falling asleep. The father sleeping in the next room has a dream about his son, who is crying "Father, don't you see I'm burning?" The father is awakened by this request and discovers that, in reality, the child is burning because of a fallen candle. The words that the boy cries out actually represent his father missing the crucial moment. The father fails to witness the occurrence of the moment when the candle overturns and burns his son. Lacan suggests that the father awakens from the dream because he wants to respond to the child's request. This responsiveness is exactly linked to him missing the child's death. His awakening and his attempt to respond is the repetition of the failure to see his son's death in time. In Unclaimed Experience Trauma, Narrative, and History, Cathy Caruth concludes that Lacan's analysis of the awakening is like this: “Awakening, in Lacan's reading of the dream, is itself the site of a trauma, the trauma of the necessity and impossibility of responding to another's death" (Cathy, 1996).

It is the father's identity that makes it impossible for him to accept or respond to the death of his child. Cathy Caruth proposes that the inability to respond is not because there is something wrong with our epistemology, but rather our ethical bond with others. The relationship between the father and his child is what makes it difficult for the father to understand his death.

When we apply this to the unprescence of the traumatic memory of COVID-19, the bond with the dead and the infectious, and the bond with every compatriot, explains why people choose to turn a blind eye to reality. To recognize the loss of a loved one or compatriot is like the father recognizing the loss of his child above. People attempt to discover the collective trauma of COVID-19, but ethical relationships with others do not allow it to happen.

To summarize what has been discussed previously, trauma is unpresentable because it is repressed by those who have personally experienced and witnessed it. Politics has also had a great influence on the reality of trauma. Bystanders who are not so closely related to the event read paper materials or listen to others. These sources are indirect, distorted and reproduced from narratives explained by subjects. These traumatic narratives are reinvented because people's accounts of the story rely on fragmentary and dissociative memories. The language of trauma is unreliable and their understanding of trauma is still unpresentable. Due to their ethical bonds, people choose to uncover the traumatic memory of losing someone. It is safe to say that trauma is unpresentable from different perspectives, so we have a good reason to reexamine the crisis of truth and the crisis of history.

People finally understand the real trauma due to the return of their traumatized memories. However, it is disappointing to realize that trauma experienced earlier is doubted, and even the truth in relation to national collective traumatic history should be questioned.

\section{The Negative Influence of Unpresence on Collective Trauma}

To a large extent, trauma is not only involved from the perspective of an individual, but also to a group. When individual trauma has been largely exposed to the limelight, people also begin to focus on collective trauma. Every individual in China is suffering from the traumatic event of COVID-19, and China, as an entire nation, is still struggling through this process. The trauma is now unpresent for many reasons, including its inherent belatedness, its repression and so on. China, where the mass outbreak of COVID-19 first began, is not capable of presenting the truth. When China cannot present or speak for itself, other countries witness and try to define the trauma experienced by the Chinese people.

Regarding witnessing a traumatic event, the word "otherness" could be used. The recognition of trauma though otherness is discussed when Cathy Caruth analyzes one of Freudian's works. In Gerusalemme Liberata, Freud mentions a hero named Tancred, who accidentally kills his beloved. Later, he goes into a forest and slashes his sword at a tree. Surprisingly, a voice utters and complains that he has wounded his beloved again. Through this case, Freud attempts to reveal the repetition of trauma, while Cathy puts forward that "there is enigma of the otherness of a human voice that cries out from the wound, a voice that witnesses a truth that Tancred himself cannot fully know" (Cathy, 1996). Through this, we can see that the voice or explanation offered by other people might result in an enigma for the sufferer. When Tancred unwittingly kills his beloved, he cannot fully recognize what has happened because of the belatedness. Nevertheless, when later coming to realize the truth of his beloved's death from the words of the tree, he would be trapped in an awkward moment. It is the moment when the known and the unknown suddenly juxtapose. This moment poses a great threat on his consciousness or, more precisely, it challenges his consciousness at this crucial moment. 
Here, someone would doubt the otherness in this poetic story of Tancred. In the story, the tree does not represent a true person but the inner voice of Tancred himself. The role of the tree is like the nightmares or the flashbacks of the sufferer. However, I would suggest that when Tancred encounters the tree who speaks for his beloved, he believes it is a real person. So, it is meaningful and reasonable here to take this case as an example to discuss otherness during a traumatic event.

Regardless of whether the person here is real or imagined, it makes sense that the truth cannot be presented via a third person, at the moment when the trauma occurs, because the truth is masked not only for the people directly involved, but also for those indirectly involved. The witness or the otherness here is also included as the sufferers of the trauma as Luckhurst mentions, "the secondary victims now include witnesses, bystanders, rescue workers, relatives" (Roger, 2008). Belatedness, as an obvious feature of trauma, would definitely prevent people from knowing the truth when it has just occurred. Even though it remains unknown for everyone, no one can stop other people's attempts to explain or judge the sufferers. At the same time, it is very easy to predict what this attempt might lead to. With unreliable reconstructions created by other people, the sufferers are likely to be subjected to an identity crisis. Symptoms such as self-suspicion and the degradation of self-esteem would emerge. So, in this section, I will discuss the influence of otherness on individual and collective trauma.

\subsection{Otherness}

Traditionally, otherness has been referred to as a perpetrator by many theorists. During alarming catastrophes, such as the Vietnam War, the Second World War, the Holocaust and Hiroshima, perpetrators would normally choose to deny the truth because "the memory of trauma poses a threat to collective identity that may be addressed by denying history, minimizing culpability for wrongdoing" (Gilad, 2018). They do not acknowledge and deny their violence to prevent the crisis of group identity. However, for recipients, it would also lead to a severe threat to their collective identity. I will mainly focus on the suffering of victims or recipients from the perspective of the threat posed on their identity. Different from the analysis of war trauma, this section will delineate how an individual or nation are influenced by otherness in the case of the pandemic, that is, how China and the Chinese people react to judgement from other countries during the COVID-19 pandemic.

\subsection{The Influence of Otherness on Collective Trauma}

In The Context and Content of Social Identity Threat, the co-authors systematically discuss the issue of the identity threat in different forms. They create a taxonomy to categorize social identity threats into four classes. Chinese suffering from COVID-19 is more likely to fall into the "Categorization threat" group. It refers to "being categorized against one's will" (Branscombe, Naomi, Russell, \& Doosje, 1999). In detail, it states that when people interact with each other, they expect to be treated fairly according to their personal characteristics. However, if they are roughly categorized in terms of their group membership - and it is possible for them to be unfairly treated due to their gender, ethnic background, or political orientation-it seems unjust.

Meanwhile, when China experienced the first outbreak of COVID-19, Chinese people were inevitably categorized by people around the world without any particular evidence of the origin of the virus. This caused prejudice towards Chinese people in many cases. For instance, according to a global poll launched by Ipsos MORI in the UK, " $14 \%$ of them would avoid contact with people of Chinese origin or appearance" (Kelly, 2020); "Twitter sees 900\% increase in hate speech towards China because of the coronavirus" (Ivan, 2021); and "Asian Americans Share Experiences of Racism During COVID-19" (Sumie, 2020). Through this news from around the world, we can see people shunned the Chinese people to avoid infection even though the origin of the pandemic still remains unclear. Thus, it is not difficult to infer how harsh it was when Chinese people were labeled as the hosts of the virus. "People feel they are treated unjustly as a result of such inappropriate categorization, they are not only likely to express anger, but they may also suffer lowered self-esteem" (Gerda, Daan, Francien, Riel, \& HAM, 1993). At this time, Chinese people may have felt under the threat of individual identity. Ellemers and coauthors also suggest that "when high-performing individuals are included in a group that is low in status or that has received a negative evaluation, disidentification is likely to result" (Naomi, Van, $\&$ Wilke, 1990). The impact of individual disidentification would create a vicious circle whereby individuals are "distancing themselves from the group or even put down other ingroup members" (Naomi, Van den Heuvel, Dick de, Anne, \& Alessandra, 2004). Accumulated individual disidentification finally transforms into a social identity threat.

As a result, this would and did exert a negative influence on national development. While China is suffering the collective trauma of COVID-19, it still has to cope with its inadequate definition and categorization from other countries because it cannot present the trauma experienced during the belated period. This can be regarded as a new collective trauma and makes the situation worse for the Chinese people. The collective traumatic memory of 
this pandemic will not only originate from COVID-19 itself, but also the hasty and improper categorization from otherness. As Gilad Hirschberger stated, "collective trauma is also a crisis of meaning." It "allows groups to redefine who they are and where they are going" (Gilad, 2018). So, how China as a nation reacts to this pandemic and the misunderstandings created by otherness will influence the basic fabric of this nation.

However, though influenced by the crisis of truth and the crisis of history brought by the unspeakable factor of trauma, we could not deny there still remains a certain degree of truth. Thus, how much truth could we get from history and how could we distinguish the truth from enormous historical materials remains as a question.

\section{Conclusion}

As stated above, the paper analyzes the theoretical development of trauma and the reasons of unpresence of Covid-19 truamtic memory. And it predicts the social identify threat caused by the unpresence of it. It combines the literature trauma theory with the latest Covid-19 to show a more practical insight of trauma from the perspective of nation.

\section{Discussion}

However, though influenced by the crisis of truth and the crisis of history brought by the unspeakable factor of trauma, we could not deny there still remains a certain degree of truth. Thus, how much truth could we get from history and how could we distinguish the truth from enormous historical materials remains as a question.

\section{References}

Anne, W. (2004). Trauma Fiction. Edinburgh: Edinburgh University Press.

Branscombe, N. R., Naomi, E., Russell, S., \& Doosje, E. J. (1999). The context and content of social identity threat. In Social Identity (pp. 35-38). Oxford U.K: Blackwell.

Cathy, C. (1995). Trauma Explorations in Memory. Baltimore and London: The Johns Hopkins University Press.

Cathy, C. (1996). Unclaimed Experience, Trauma, Narrative, and History. Baltimore and London: The Johns Hopkins University Press.

Dori, L., \& Shoshana, F. (eds.). (1991). No One Bears Witness to the Witness, in Testimony: Crises of Witnessing in Literature, Psychoanalysis, and History. New York: Routledge, https://doi.org/10.5860/CHOICE.29-6108

Gerda, K., Daan, V. K., Francien, B., Riel, V., \& HAM, W. (1993). Procedural fairness and self-esteem. European Journal of Social Psychology, 23, 313-325. https://doi.org/10.1002/ejsp.2420230307

Gilad, H. (2018). Collective Trauma and the Social Construction of Meaning. Frontiers Psychology, 9, 1441. https://doi.org/10.3389/fpsyg.2018.01441

Ivan, M. (2021, March 27). Twitter sees 900 increase in hate speech towards China because coronavirus. Retrieved from https://thenextweb.com/world/2020/03/27/twitter-sees-900-increase-in-hate-speech-towards-china-becausecoronavirus/

Jean, F. L. (1984). The Postmodern Condition: A Report on knowledge. In G. Wlad \& S.-S. Jochen (Eds.), Theory and History of Literature (Vol. 10). Minneapolis: University of Minnesota Press.

Jeffery, C. A., Ron, E., Bernhard, G., Neil, J. S., \& Piotr, S. (2004). Cultural Trauma and Collective Identity. Berkeley. Los Angeles. London: University of California Press. https://doi.org/10.1525/9780520936768

Kelly, B. (2020, February, 14). COVID-19 One in seven people would avoid people of Chinese origin or appearance. Retrieved from https://www.ipsos.com/ipsos-mori/en-uk/COVID-19-one-seven-people-would-avoid-people-chinese-originor-appearance

Mather, R., \& Jill, M. (2004). Trauma and Temporality: On the Origins of Post-traumatic Stress. Theory and Psychology, 14(2), 205-219. https://doi.org/10.1177/0959354304042017

Michelle, B. (2014). Contemporary Approaches in Literary Trauma Theory. London: Palgrave Macmillan. https://doi.org/10.1057/9781137365941

Naomi, E., Van den Heuvel, H., Dick de, G., Anne, M., \& Alessandra, B. (2004). The underrepresentation of women in science: Differential commitment or the queen bee syndrome? British Journal of Social Psychology, 43, 315-318. https://doi.org/10.1348/0144666042037999 
Naomi, E., Van, K. A., \& Wilke, H. (1990). The influence of permeability of group boundaries and stability of group status on strategies of individual mobility and social change. British Journal of Social Psychology, 29(3), 233-246. https://doi.org/10.1111/j.2044-8309.1990.tb00902.x

Roger, L. (2008). The Trauma Question. London and New York: Routledge.

Shoshana, F. (1985). 'Don’t You See I'm Burning?' Or Lacan and Philosophy. In Writing and Madness (pp. 134-140). Ithaca: Cornell University Press.

Sumie, O. (2020, June 25). Asian Americans Share Experience of Racism During COVID-19. Retrieved from https://time.com/5858649/racism-coronavirus/

Van der Kolk, B. (1996). Trauma and memory. In B. Van der Kolk, A. C. McFarlane \& L. Weisaeth (Eds), Traumatic stress. Bessele. London: Guilford.

Young, A. (1995). The harmony of illusions: Inventing Post-Traumatic Stress Disorder. Princeton: Princeton University Press. https://doi.org/10.1515/9781400821938

\section{Copyrights}

Copyright for this article is retained by the author, with first publication rights granted to the journal.

This is an open-access article distributed under the terms and conditions of the Creative Commons Attribution license (http://creativecommons.org/licenses/by/4.0/). 